\title{
The Goddess on the Vezirhan Stele
}

The stele from Vezirhan (Istanbul Archaeological Museum, inv. 6219+71.27) is best known for its Old Phrygian and Greek inscriptions (B-05). However, its reliefs also pose an interesting challenge. They include a boar hunt, a ritual banquet scene, and a human figure, commonly identified as a goddess, with lions, birds, and a palmette-like motif "sprouting" from her head.

The stele is dated to the late $5^{\text {th }}$-early $4^{\text {th }}$ century BC. The hunt and banquet scenes clearly belong to this time (and find many parallels on votive and funerary reliefs and seals of Hellespontine Phrygia).

The image of the goddess, however, continues a different tradition, one that possibly stems from an earlier period. The Vezirhan goddess doesn't have a singular prototype, but displays connections to a wide variety of iconographical schemes and details. Most are found in the $7^{\text {th }}-6^{\text {th }}$ centuries $\mathrm{BC}$ arts of Anatolia and the Aegean. By examining this corpus, with special focus on the Potnia theron iconographic type, we understand that the Vezirhan goddess is related to other deities attested in Anatolia (in fact, her name might have been a variation of Artemis, according to line 3 of the Phrygian inscription). Yet, she cannot be identified with any of them directly. For all matches, there are also differences. A certain creative effort was made to distinguish the goddess from her peers, possibly to reflect her local cult.

In my talk, I would like to unfold this synthetic image, examine its components, and try to put them back together - and hopefully gain some insight into how the Vezirhan goddess' iconographic scheme came to be. 